Hunter graduated from the University of Leeds, of which he was a D.Sc., and started his researches into barley breeding in the early 1900's. This early work was conducted in Ireland, where he was head of the Plant Breeding Division, Department of Agriculture, Dublin, while he also became the first director of the Stormont Plant Breeding Station in Northern Ireland. Later, during 1936-46, Hunter was director of the Cambridge University Plant Breeding Institute. When in Ireland he bred the hybrid barley variety, Spratt-Archer, which was afterwards to make his name when it became one of the most successful varieties of cereals ever bred for Great Britain. It was introduced into cultivation in 1914, and has only been superseded as a standard malting barley in recent years. Hunter went to Cambridge in 1924, and he there bred two more varieties of barley-Earl and Camton-and a winter oat variety named Picton. All these varieties found a place in British agriculture and received official recommendation for farmers. Hunter's contributions gave him an established position with Sir Rowland Biffen and Dr. E. S. Beaven as successful pioneer plant breeders exploiting the new genetic knowledge.

This work ensured the recognition of Hunter's name nationally and internationally, but ho also acquired a great reputation as a writer. He started contributing scientific papers and articles as early as 1908 , and maintained a steady output throughout his life. He was an easy, lucid and fluent writer, and found an outlet for his talent in writing books, of which he had a number of successes to his credit. $\mathrm{He}$ wrote a standard work on oats, and one on barley in the 1920's, while in 1931 he edited a new edition of Baillière's "Encyclopædia of Agriculture" (with H. Martin Leake), while his most recent contributions were "Crop Varieties" (1954) and "The Barley Crop" (1956).

One of Hunter's great interests was the work of the National Institute of Agricultural Botany, to which he gave most valued service as a member of Council for twenty-one years, as acting director during the Second World War, and as chairman of Council for three years. For his services he was elected a vice-president of Council, a signal recognition of the way in which he guided the Institute's work and activities and established its present important relationships with agriculturists and commercial interests in the seed trade. Hunter's great tact, wisdom and kindliness were all instrumental in accomplishing this work so successfully, and those who worked under him in both Institutes which he directed were grateful for the experience.

In 1911 Herbert Hunter married Rosa Wise, of Springfield, Ohio. She died in 1945, and Hunter married in 1951 Mrs. Blanche Metters, widow of J. D. Metters. He is survived by his widow and two daughters of his first marriage. G. D. H. BELL

\section{Dr. Alexander M. Cockburn}

ON February 28 Dr. Alexander Murray Cockburn, senior lecturer in geology in the University of Edinburgh, died at the age of fifty-seven.

Dr. Cockburn graduated with first-class honours in geology at Edinburgh in 1924. After a season with the Geological Survey of Canada, and some time spent in studying volcanic phenomena in Hawaii, he returned to his native city to take up postgraduate research as a Falconer Fellow of the University. In
1927, with John Mathieson, Dr. Cockburn carried out the first detailed topographic survey of the St. Kilda group of islends, and in the following year he completed a geological study of these islands, which was published in the Transactions of the Royal Society of Edinburgh in 1935, and remains a distinguished contribution to our knowledge of Scottish geology.

Dr. Cockburn was awarded the degree of Ph.D. in 1929, and was elected a Fellow of the Royal Society of Edinburgh in 1935. He began his long service as a member of the staff of the University of Edinburgh in 1931, and passed successively through the positions of assistant and curator of the museum, lecturer, and senior lecturer. In 1942, he took over from Prof. T. J. Jehu the courses in stratigraphy, and since then he was responsible for the formal stratigraphy courses in the Department. However, he never lost his early interest in vulcanology, and he made a comprehensive study of the volcanic rocks of the Pentland Hills. It is most unfortunate that his early death should have prevented him from publishing more than a small part of this work.

From 1951 onwards Dr. Cockburn acted as director of studies in pure science, and he was a member of the Senatus Academicus of the University of Edinburgh from 1956. A prominent Fellow of the Edinburgh Geological Society, he served as honorary secretary during 1939-44, and was elected president in 1958 .

These few details of Dr. Cockburn's career can reveal little of the enormous debt which is owed to him by his Department and by all who have been associated with it. $\mathrm{He}$ combined a complete and unselfish loyalty to his subject and his Department with a deep and stimulating understanding of the personal problems of his students. He was a most able and conscientious teacher, both in the lecture room and in the field, and he carried a considerable administrative load. One of his great interests was the geological museum, and to this, and to the care of the Grant Institute building, he devoted a great deal of time and skill. Recently he has played a large part in the planning associated with a new building programme, and in the change from a threeyear to a four-year honours course in geology. All the students who came under his care will remember with gratitude and affection the help and advice which he gave so readily, and his unfailing kindness, wisdom and good humour. All who were fortunate enough to know him feel a tragic sense of personal loss.

F. H. STEWART

\section{Dr. S. Bekku}

BY the death on September 19 last in Tokyo of Dr. S. Bekku, Japan has lost one of her distinguished electrical engineers.

Dr. Bekku was born at Ueno, Tokyo, in 1893, and he graduated in electrical engineering from the Tokyo Imperial University in 1917. After graduation he pursued advanced studies in the Electro-Technical Laboratory on electrical power transmission and high-voltage engineering. It was at this stage that Dr. Bekku had the opportunity of going to the United States and working with the Westinghouse Electric Company under the direction of Dr. C. L. Fortescue. In 1927, Dr. Bekku received the degree of doctor of engineering from the Tokyo Imperial University, and in 1928 he was appointed to a professorship in the Tokyo Institute of Technology. Here he lectured on transmission and high-voltage engin- 
eering. In 1931, Dr. Bekku took up an appointment with the Sumitomo Electrical Industries, where he was responsible for important research and development work in the field of electrical power transmission and distribution.

During the period up to the outbreak of the Second World War, Dr. Bekku published papers dealing with measurements on overhead transmission lines, unbalanced alternating current circuits, concentric cables and power capacitors.

In 1952, Dr. Bekku was elected president of the Institution of Electrical Engineers of Japan. In
1956, the Central Power Research Laboratory, a research association which serves the nine major electricity supply organizations in Japan, appointed Dr. Bekku its director and he was responsible for work on the development of the $380-\mathrm{kV}$. transmission system.

Dr. Bekku took great pleasure in the maintenance of his contacts with electrical engineers and physicists in the United States. He had travelled extensively in Europe and America and he enjoyed climbing and skiing. Dr. Bekku is survived by his widow, two sons and two daughters.

\section{NEWS and VIEWS}

\section{The Rockefeller Foundation: New Officers}

Dr. J. George Harrar has been elected vicepresident of the Rockefeller Foundation. Dr. Robert S. Morison has been elected director for medical and natural sciences, a programme merging the biological, medical and public health interests of the Foundation. Dr. John C. Bugher is to be consultant on nuclear energy and as a principal officer will assist all programmes with respect to the impact of nuclear energy. Dr. Albert H. Moseman has been appointed deputy director for agricultural sciences, the new designation of the former agricultural progxamme. Dr. Lindsley F. Kimball continues as executive vice-president and Dr. Warren Weaver as vice-president for the natural and medical sciences.

Dr. Harrar joined the Foundation in 1943 as local director for the agricultural operating programme in Mexico. He became deputy director for agriculture in 1952 and director in 1955 . Dr. Harrar is also serving in a special capacity as director of the National Academy of Sciences Survey on Education, Science and Technology in Africa south of the Sahara. When he joined the Foundation he was the sole staff of its agriculture programme. Established with Dr. Harrar's arrival in Mexico in 1943, this agricultural programme now has operating units in Mexico, Colombia, Chile and India, an extensive international fellowship and scholarship plan, and a grants programme in support of agricultural research and education. Approximately 6,270,000 dollars was appropriated last year by the Foundation in support of these three types of activities.

Dr. Morison was formerly director for biological and medical research in the Foundation. A graduate of Harvard University and of the Harvard Medical School, he taught in the latter before joining the Foundation in 1944. Dr. Bugher, a member of the Foundation's staff since 1943, was given leave of absence to serve for four years as director of the Division of Biology and Medicine of the U.S. Atomic Energy Commission. He returned to the Foundation in 1955 as director for medical education and public health. He represented the Atomic Energy Commission officially at the Geneva Conference on the Peaceful Uses of Atomic Energy in 1958 and is $a$ member of the Commission's advisory committee on biology and medicino. Dr. Moseman joined the Foundation in 1956. $\mathrm{H}_{\ominus}$ was previously director of crops research of the agricultural research service of the U.S. Department of Agriculture.

\section{National Science Foundation Office of Social Sciences}

The National Science Foundation has recently established an Office of Social Sciences with Dr. Henry W. Riecken as its head. The Foundation has also appointed an Advisory Committee for the Social Sciences to advise on programmes and policy, the members of which are: Dr. Leonard S. Cottrell, social psychologist, Russell Sage Foundation; Prof. Fred Eggan, professor of anthropology, University of Chicago; Dr. John Gardner, president, Carnegie Corporation; Dr. Pendleton Herring, president, Social Science Research Council; Prof. Joseph Spengler, professor of economics, Duke University; Prof.S. S. Wilks, professor of mathematics, Princeton University; and Dr. Dael Wolfle, executive secretary, American Association for the Advancement of Science. The National Science Foundation intends to support basic research in the social sciences, since such support is invaluable in assisting social scientists to improve their research techniques, to accumulate fundamental knowledge about human behaviour and society, and to develop sound theoretical bases for further inquiry.

\section{British Scientific Attaché in Moscow:}

Mr. D. A. Senior

Mr. D. A. Senror, of the Royal Naval Scientific Service, has been appointed to the newly created post of scientific attaché to the British Embassy in Moscow; he will advise the British Ambassador, Sir Patrick Reilly, on scientific matters and report on Soviet scientific and technical development in the civil field. Mr. Senior, who is thirty-five, will hold the rank of senior principal scientific officer and will be on the staff of the Department of Scientific and Industrial Research. Mr. Senior attended Batley Grammar School, Yorks, where ho won an open scholarship to Trinity College, Cambridge. $\mathrm{He}$ graduated at Cambridge in 1943 with first-class honours in mechanical sciences (with distinction in electronics). He also won the Charles Lamb Prize in electrical engineering. In 1946 he shared the John Wimbolt Prize in civil engineering. From Cambridge he entered the Naval Construction Research Establishment at Rosyth, where he worked on high-speed photography. Since $1950 \mathrm{Mr}$. Senior has been at the Admiralty Research Laboratory, Teddington, mainly investigating problems of instrumentation and combustion. Recently, he carried out a study of acoustic 